\title{
Quality as Driver for Sustainable Construction-Holistic Quality Model and Assessment
}

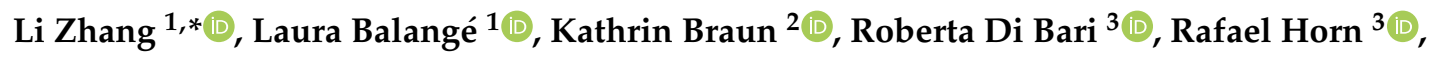 \\ Deniz Hos ${ }^{2}$, Cordula Kropp ${ }^{2}$, , Philip Leistner ${ }^{3}$ and Volker Schwieger ${ }^{1}$ \\ 1 Institute of Engineering Geodesy (IIGS), University of Stuttgart, D-70174 Stuttgart, Germany; \\ laura.balange@iigs.uni-stuttgart.de (L.B.); volker.schwieger@iigs.uni-stuttgart.de (V.S.) \\ 2 Institute for Social Sciences (SOWI), University of Stuttgart, D-70174 Stuttgart, Germany; \\ kathrin.braun@sowi.uni-stuttgart.de (K.B.); patrick-deniz.hos@sowi.uni-stuttgart.de (D.H.); \\ cordula.kropp@sowi.uni-stuttgart.de (C.K.) \\ 3 Institute for Acoustics and Building Physics (IABP), University of Stuttgart, D-70563 Stuttgart, Germany; \\ roberta.di-bari@iabp.uni-stuttgart.de (R.D.B.); rafael.horn@iabp.uni-stuttgart.de (R.H.); \\ leistner@iabp.uni-stuttgart.de (P.L.) \\ * Correspondence: li.zhang@iigs.uni-stuttgart.de
}

Received: 30 July 2020; Accepted: 21 September 2020; Published: 23 September 2020

check for updates

\begin{abstract}
Facing rising building demands due to a fast-growing world population and significant environmental challenges at the same time, the building sector urgently requires innovation. The Cluster of Excellence Integrative Computational Design and Construction for Architecture at the University of Stuttgart tackles these challenges through a Co-Design approach for integrating computational design and engineering and robotic construction. Within this research framework, a Holistic Quality Model is developed to ensure the technical, environmental, and social quality of Co-Design processes and products. Up to now, quality models that consider and integrate all these three aspects throughout the life cycle of buildings are still missing. The article outlines the concept of holistic quality assessment based on a Holistic Quality Model for sustainable construction. A key mechanism for sustainable quality assessment in the Holistic Quality Model is the definition of control and decision points in the construction process where critical decisions are made that will affect the quality of the building throughout its entire life-cycle. Firstly, subject-specific quality concepts are defined and their interrelations are conceptualized. Subsequently, these interrelations and their effects on the overall Co-Design construction processes and products are explained using the example of the semi-robotic production of concrete slabs. Examples for control and decision points are given as well. The outline presented here serves as a basis for further advancing and concretizing the Holistic Quality Model and its applications in Co-Design for a functioning, liveable, and sustainable high-quality construction and building culture.
\end{abstract}

Keywords: co-design; quality characteristics; quality parameters; computational design; computational construction; predictive quality assessment; control points; decision points

\section{Introduction}

\subsection{Co-Design: Scope and Ambition}

The building and construction industry accounts for 36\% of global energy use and 39\% of process-related $\mathrm{CO}_{2}$ emissions and the building stock is still expected to double by 2050 [1]. According to the UN, the world's population is projected to grow from 7.7 billion people in 2019 to 9.7 billion in 2050 [2]. The percentage of people living in urban areas is projected to grow from $55 \%$ in 2018 to $68 \%$ in 2050 [3]. There is a broad discussion about what cities must be able to achieve in the future in order to 
enable good and decent ways of living together and meet sustainability goals and which technical and functional prerequisites must be fulfilled in order to achieve them [4]. The challenge is to safeguard and reconcile requirements of environmental sustainability, technical functionality, and social quality, such as quality of life and user-friendliness of buildings, especially against the background of climate change, environmental crisis, and a growing world population.

The Cluster of Excellence Integrative Computational Design and Construction for Architecture (IntCDC) at the University of Stuttgart, Germany, is an interdisciplinary, large-scale research cluster that tackles these challenges. It brings together methods, processes and systems based on interdisciplinary research encompassing architecture, structural engineering, building physics, engineering geodesy, manufacturing and systems engineering, computer science, and robotics, as well as humanities and social sciences. IntCDC develops a series of new technologies like lightweight and hybrid construction materials, on-site prefabrication, fibre-composite building elements, and robotic assembly, but also a new Co-Design approach based on digitalisation and cyber-physical production systems for design and construction. Briefly, Co-Design describes the close interaction and deliberate integration of different planning and execution phases to overcome the linearity and fragmentation of the construction process. The Co-Design approach is supposed to make a significant contribution to providing the prerequisites for a high-quality, liveable and sustainable built environment, and digital building culture.

Within this context, a Holistic Quality Model (HQM) will be developed that will serve the purpose of evaluating building performance with respect to technical, environmental and social quality characteristics and their interrelations (Figure 1). It will inform those involved in the construction process about potential effects of their decisions on technical, environmental and social quality so that they can take corrective action if need be. The overall purpose of the HQM is to contribute to more sustainable and high-quality buildings and construction processes.

\begin{tabular}{|c|c|c|c|}
\hline Background & \multicolumn{3}{|c|}{ Integrative Computational Design and Construction (IntCDC) } \\
\hline Goals & \multicolumn{3}{|c|}{ Model of Quality, Assessment of Quality, Support of Decisions } \\
\hline Approach & \multicolumn{3}{|c|}{ Holistic Quality Model and Assessment for Co-Design in Construction } \\
\hline \multirow[t]{2}{*}{ Aspects } & Social Quality & Environmental Quality & Technical Quality \\
\hline & $\begin{array}{l}\text { Adaptable usability, decent } \\
\text { work, accessibility, } \\
\text { flexibility... }\end{array}$ & $\begin{array}{l}\text { Global warming potential, } \\
\text { erosion, human toxicity } \ldots\end{array}$ & $\begin{array}{l}\text { Accuracy, correctness, } \\
\text { completeness, load-bearing } \\
\text { resistance, timeliness... }\end{array}$ \\
\hline \multirow[t]{2}{*}{ Interrelations } & - & 2 & 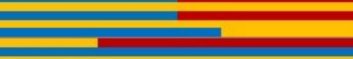 \\
\hline & \multicolumn{3}{|c|}{$\begin{array}{l}\text { e.g. interrelated consequences of human-machine-interaction on social (flexibility, decent } \\
\text { work), environmental (Global warming potential, erosion) and technical (timeliness, } \\
\text { correctness, load-bearing resistance) quality }\end{array}$} \\
\hline Concept & \multicolumn{3}{|c|}{$\begin{array}{l}\text { Requirements, characteristics, parameters, criteria, control points, } \\
\text { decision points }\end{array}$} \\
\hline
\end{tabular}

Figure 1. Holistic Quality Model (HQM) and Assessment for Co-Design in Construction.

A quality model is application-oriented and based on requirements. It consists of the quality characteristics, quality parameters, criteria, and interrelations that enable description and modelling of the quality structurally (for their definitions see Section 2.1). Different technical quality models have been established for different applications (see Section 2.2), however, to date, no quality model has been developed which integrates more than just technical aspects. The HQM will break new ground in that it takes a decisively interdisciplinary approach. It is based on requirements and consists of technical, environmental, and social quality characteristics and parameters and integrates different quality aspects into one quality model by considering the interrelations. The main challenge for setting up the HQM 
is to specify the interrelations among the three quality aspects and render them manageable. In this project, disciplinary reflections support the interdisciplinary work on quality characteristics based on concepts of socio-cultural quality and social sustainability [5,6], life cycle assessment (LCA) for environmental quality (ISO 14040-14044), and technical quality model development for the integration of technical quality characteristics [7]. On this basis, one model will be set up for considering the different quality characteristics and parameters and the interrelations between them. The digitalisation and automation of construction processes will influence the form of human-machine-interaction, and therefore influence the interrelations between technical, environmental, and social characteristics.

The HQM is the focus of this paper and can describe the quality processes and products holistically. Based on the HQM, control and decision points are defined to assess the quality of processes and products in a holistic way. The idea is to define points in the construction process where quality control takes place (control points) and quality-relevant decisions are taken (decision points) in order to allow quality-relevant considerations to take place at an early stage in the construction process.

From this perspective, high holistic quality of building life cycles refers to conformity with standards (technical quality), a fair and decent production process and liveable, user-friendly buildings that allow for social wellbeing and a good life for a diversity of users (social quality), and compliance with planetary boundaries and the least possible impact on the natural environment (environmental quality). The holistic quality concept that will be developed requires a global perspective on questions of inter- and intragenerative, social and environmental justice and is in this sense fundamentally oriented towards sustainable development.

\subsection{State of the Art in Construction Processes}

A construction process is usually a precisely defined and linear process which goes through the phases of definition, planning, execution, and use as well as end-of-life [8] and describes the life cycle of buildings. Figure 2 shows the five phases and their associated information or digital tools. In addition, the management of the construction process, including financial controlling, resource planning and cooperate planning, also plays an important role during the whole process; however, they are not the focus of this paper, so Figure 2 does not explicitly address them.

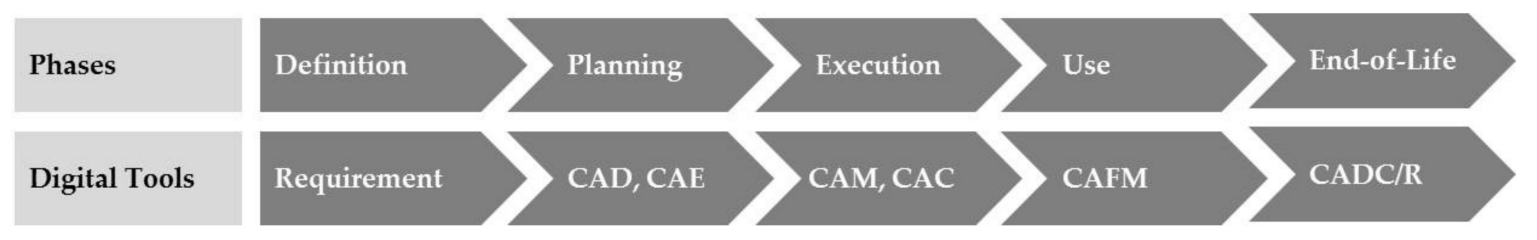

Figure 2. Construction process and digital tools (CAD: Computer Aided Design, CAE: Computer Aided Engineering, CAM: Computer Aided Manufacturing, CAC: Computer Aided Construction, CAFM: Computer Aided Facility Management, CADC/R: Computer Aided Deconstruction/Recycling).

As illustrated in Figure 2, the requirements of the construction need to be defined based on their future function at the beginning of the construction process, meaning in the definition phase [8]. The basic task here is to construct a building with the required functionality and budget within the planned schedule. In addition, also safety, health and environmental aspects should be considered [8]. The planning phase consists of architectural design and structural planning. Digital tools such as CAD and CAE have long been applied in the planning phase. Although the on-site construction is still mainly a manual process, the digital prefabrication and digitalisation is the trend of the construction process [9]. The execution phase refers to off-site prefabrication, on-site fabrication, and on-site assembly. The use phase of the building provides the user with the functions of the building. After completion, the main tasks in the use phase are facility management and maintenance and repair of the building, but also more comprehensive measures such as replacements or refurbishments. While this phase is oftentimes not digitalised, tools for facility management are available and increasingly applied [10]. At the end of 
the building service life is the end-of-life phase, which includes the deconstruction and potential reuse and recycling of buildings.

In practice, due to financing and time constraints, parallel processes usually replace this sequential linear process and there is no feedback between the phases. Therefore, this process often results in problems such as short planning times, high susceptibility to errors in the construction process, information overload on construction sites and, often, conflicts over deadlines and costs [8].

Building Information Modelling (BIM) is a digital tool to facilitate collaboration between planners, engineers and other stakeholders. Its uptake has increased in recent years, but many parties are still rather reluctant for a number of reasons, particularly in Europe. Reservations are related to, among other things, a lack of trained personnel and technical expertise, increased operational costs at the beginning and other the well-known resistance to change in the construction sector [11]. In short, current approaches mainly focus on the establishment of a linear digital chain for the sequential construction process phases. Co-Design, which will be introduced in Section 3.1, is, in contrast, supposed to achieve a non-linear construction process [12,13].

\subsection{Sustainability in the Construction Sector}

Several works indicate that the construction industry, even within strong economic environments, is suffering from low productivity, which has been stagnating since the 1990s [14,15]. At the same time, the sector is being held responsible for significant environmental impacts, including $40 \%$ of global energy consumption and $50 \%$ of global waste [15]. Furthermore, the construction sector has been vulnerable to phases of exuberant activity followed by economic bottlenecks with many insolvencies [16,17], problematic working conditions (some of which are on the verge of legal employment), one-sided profit optimization [18], and the high environmental impact of buildings of questionable necessity [19]. In order to achieve environmental enhancement, most of the strategies have focused so far on energy saving, which only solves this issue partially and do not consider, for instance, resource-efficiency and indirect emissions [16]. Last, but not least, while the population is increasing and resources destined to dwellings, offices and the like are growing, part of the world population is still lacking sufficient living space [20].

Such paradoxical situations have been already largely discussed among countries, which have subscribed to a commitment for new sustainable development within the Agenda 2030 and Sustainable Developments Goals (SDGs) [21]. As emphasized by the World Green Building Council, new building design can contribute towards meeting several SDGs, by improving people's wellbeing and promoting new sustainable cities and communities. An innovation of the whole building industry can furthermore spur new climate-resilient construction, create new job opportunities and improve the environmental performance of buildings [22].

Tangible and meaningful indicators for the assessment of environmental sustainability of products and, consequently, for an alignment of targets with specific SDGs, are provided by life cycle approaches: among them, Life Cycle Assessment (LCA) [23]. LCA is a methodology developed in the last decades based on the framework and specifications in the ISO14040 and ISO14044 standards. It is a technique for assessing the environmental aspects associated with a product/service over its life cycle and used for the analysis of the contribution of the life cycle stages to the overall environmental load, for comparison between products, strategic planning, marketing and other purposes.

In an analogous form, several approaches have tried to identify social impacts, such as Social Impact Assessment (SIA) and Life Cycle Sustainability Assessment (LCSA). SIA is a methodology to evaluate social effects of infrastructure projects as well as unexpected events, such as disasters, demographic change and epidemics. LCSA refers to the evaluation of all environmental, social, and economic negative impacts and benefits in decision-making processes towards more sustainable products throughout their life cycle, by combining results coming from LCA, Life Cycle Costing (LCC) and Social LCA [24]. Due to their complexity, unlike LCA, these are still under discussion in order to establish an international standard. 
In a more concrete way, there are ongoing initiatives which aim to exploit such methodologies within the product design process, i.e., design for sustainability. Hereby, holistic life cycle approaches will be an integral part of product development and provide feedback to improve its functionality, technical performance, increase product lifetime or promote a sustainable users behaviour [25].

More specifically for buildings, sustainable building assessment (SBA) and certification systems are widespread. A first generation of building certification systems (e.g., BREEAM) has tried to address sustainability assessment in a qualitative form [26]. More recently, a new generation of certification systems (e.g., DGNB) has quantified the environmental performance of buildings products and, unlike the first generation, revolves not only around environmental aspects but also includes a holistic examination of the entire life cycle of a building or urban district [27].

Despite such developments and the growing awareness of sustainability issues, the environmental performance assessment of buildings and building construction occurs only in retrospect, after the process has been completed. Due to the lack of information during the early stages, sustainability assessment is aimed at obtaining a certificate for the building and not at providing timely feedback for improving the sustainability of product and process [28].

In conclusion, the role of LCA and its contribution to sustainable construction are still topics that deserve in-depth discussion. When building processes become more and more complex in all fields and especially with regard to building sustainability, new digital tools and new expertise are required in order to offer construction alternatives and promote environmental values from the beginning [29,30].

\subsection{Research Gap and Hypothesis}

It seems that technical, environmental, and social quality aspects interrelate and cannot be pursued independently from each other. Yet, at present, quality models which systematically consider and integrate technical, environmental and social quality aspects of buildings and construction processes throughout the life cycle of buildings are still missing. Accordingly, conventional quality assessment cannot take possible long-term effects of such interrelations into account, thus missing many opportunities for making buildings and construction processes more sustainable.

Since the Co-Design construction process is non-linear, Co-design will considerably increase the complexity of the construction process and the resulting interdependence of different quality aspects. Thus, new tools are required to ensure quality under conditions of increased complexity. Four levels of hierarchy (for a definition see Section 3.1) are defined to support the Co-Design approach. Therefore, a deeper understanding of how different quality aspects are interrelated and interdependent throughout the different construction phases and between different levels of hierarchy can contribute to improving the ability to control construction processes and achieve better results.

To make a significant contribution to establishing a high-quality sustainable building industry, a quality assurance concept which consists of the HQM and holistic quality assessment is developed and will be introduced in Section 2. The HQM starts from the assumption that every material or building component that is used and processed will affect environmental, social, and technical quality characteristics, not only at a certain point in time or concerning a certain construction phase or level of hierarchy, but throughout the entire life-cycle of the building. The model will help to identify and facilitate quality-relevant options at crucial decision points (for a definition see Section 2.1) which affect a set of coherent quality characteristics and thereby allow for improved decision-making. Mapping those connections over the different phases and levels of hierarchy can clarify the implications of certain decisions.

An HQM allows for the realization of quality and sustainability-related goals through a consistent identification and addressing of control points (for a definition see Section 2.1) and decision points for quality assessment. Throughout the whole construction process, the model considers technical, environmental, and social quality characteristics and their interrelations. While specifying the different quality characteristics requires different disciplinary contributions, one joint model can address the different aspects and identify connections and their overall influence on quality. Giving feedback 
at defined control and decision points over the entire construction process will not only allow in evaluating, but also, if need be, to intervene in the construction process in order to secure and improve quality. Hereby, the HQM not only allows to equally consider different kinds of quality and their interrelations in the complex non-linear construction process but also a real-time quality assessment at an early stage regarding the entire building life cycle.

\section{Quality Assurance Concept and Quality Models for Co-Design in Construction}

\subsection{General Definition and Quality Assurance Concept}

Quality assurance is part of quality management and focuses on providing confidence in the fulfilment of quality requirements [31]. As illustrated in Figure 3, the quality assurance concept consists of two parts: a holistic quality model, which holistically describes the quality of processes and products in the context of Co-Design in construction, and a holistic quality assessment, which realizes the evaluation of quality in a holistic way.

Quality is defined as the "degree to which a set of inherent characteristics fulfils requirements" [31]. As illustrated in the left part of Figure 3, the HQM is derived from the technical, environmental and social requirements of Co-Design processes and products.

The left part of Figure 3 shows the structure of the quality model. The quality model consists of quality characteristics, which concretize the quality model. Generally, quality in the construction industry is the fulfilment of requirements of construction products (e.g., building components) and processes (e.g., the associated production processes for building components), therefore product- and process-related quality characteristics are defined.

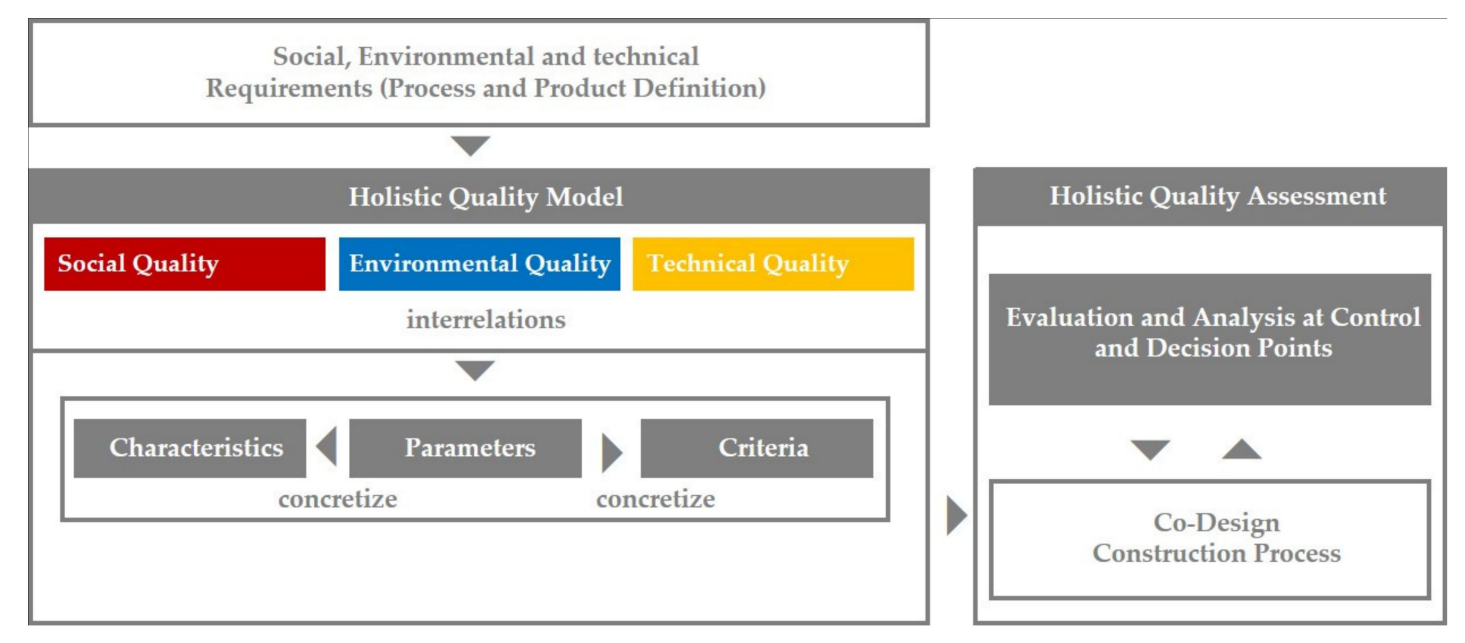

Figure 3. Quality assurance concept for the Co-Design construction process.

The quality characteristics present the structure of the quality model qualitatively. Therefore, several quality parameters (quantitative measures) are necessary to concretize the quality characteristics. For example, accuracy is one quality characteristic; the corresponding quality parameters could be the standard deviation, the maximal deviation etc. Furthermore, quality criteria are defined based on the quality parameters for quality assurance purposes. A quality criterion defines a target or a sub-target of a quality assessment, which means that optimization of one quality parameter (e.g., the standard deviation should be minimized) is needed or a critical value for a quality parameter that should not be exceeded. In some cases, instead of optimizing an individual parameter, some quality characteristics need to be optimized or should be simply available, e.g., "conversion should be possible".

Quality characteristics and parameters are application-orientated, so they derive from the requirements of different applications. Within IntCDC, a comprehensive requirement analysis through several face-to-face meetings with researchers from other research projects of the cluster was conducted. 
Moreover, an online questionnaire was created, and more than 50 participants from different disciplines responded. The respondents had to rank different potentially relevant aspects of quality. This allowed us to establish which quality characteristics are perceived as important by the respective disciplines and how the interrelations between the characteristics may be described. In addition, there was the option of open answers, so that the participants could introduce quality characteristics which had not yet been taken into account. Besides the face-to-face meetings and the online questionnaire, the relevant literature and selected key documents such as the SDGs (see Sections 2.2-2.4) was reviewed. This enabled us to document, identify and investigate the technical, environmental and social quality requirements of all the disciplines within IntCDC. Extensive quality characteristics could be derived from the requirement analysis for setting up the HQM.

The HQM is the focus of this paper, the technical, environmental, and social quality of Co-Design processes and products will be described in Sections 2.2-2.4 individually. In order to integrate all the three aspects of quality in one HQM (left part of Figure 3), the interrelations between the quality characteristics and quality parameters of these three quality aspects form the key elements within the HQM. The setup of the HQM with all three aspects will be introduced and demonstrated in Sections 3.2 and 3.3 through examples.

The holistic quality assessment (right part of Figure 3) is based on the HQM and takes place at control and decision points integrated into the Co-Design construction process.

Control points specify situations in the construction process where certain quality characteristics and parameters of processes or products can be defined, measured and assessed with regard to quality requirements. Decision points are situations in the construction process where a decision with relevant influence on process or product quality is made either by humans or by algorithms. To provide feedback on potential quality-related implications of a decision, the potential future quality characteristics and parameters resulting from the decision are predicted through simulation. The assessment performed at control points thus occurs in two ways: as a retrospective and as a predictive assessment of quality characteristics and parameters of processes or products. Retrospective assessment at control points serves to assess the quality of the actual manufacturing processes and the existing products. Predictive assessment performed at control points serves to generate information about the potential implications of the choices made at specific decision points.

\subsection{Technical Quality}

The evaluation of technical quality is of great importance in everyday life and also ranks as the most important criterion for quality assessment in the responses to the online questionnaire. Different technical quality models have been developed for different fields in recent years. These are used, for example, in software development, where the software is evaluated on the basis of quality characteristics such as correctness, efficiency, reliability, and functionality [32]. In geodesy, quality models have been defined for a long time. For instance, the accuracy, reliability, and sensitivity, as well as separability, are defined as quality characteristics for engineering geodetic networks [33]. In the field of transport telematics, a quality model has been developed which contains quality characteristics such as reliability, integrity, and accuracy [34]. In the construction sector, some technical quality models have already been developed. For example, a quality model and real-time quality assurance system for residential houses have been developed [35].

The quality assessment also plays an important role in the development of BIM. A BIM-based building quality management system has been developed [36] which contains data from the planning to the execution of the building. However, this quality management system only has a list of criteria but does not contain any quality models with quality characteristics and parameters.

For the technical quality assessment of Co-Design processes and products, the online questionnaire showed that most technical quality requirements for timber and concrete construction are derived from national and international norms and standards. In contrast, there are currently no norms and standards for the use of fibre-composites for planning and manufacture Quality characteristics, 
which are relevant for the assessment are extracted from the received standards [37-44]. In order to clarify the understanding of the technical quality characteristics, exemplary quality characteristics, parameters, and criteria are shown in Table 1 . These refer to the requirements that are defined within the framework of the requirements analysis in the project.

Table 1. Exemplary quality characteristics, parameters and criteria for the technical quality [45].

\begin{tabular}{cccc}
\hline Requirements & Quality Characteristic & Exemplary Parameters & Criteria \\
\hline DIN EN ISO 286-1 & Accuracy & Standard deviation & $\begin{array}{c}\text { Standard deviation } \\
\text { should be met }\end{array}$ \\
\hline DIN EN 18202 & Correctness & $\begin{array}{c}\text { Tolerance } \\
\text { Tolerance correctness }\end{array}$ & tolerance met \\
\hline $\begin{array}{c}\text { The building should be } \\
\text { built completely } \\
\begin{array}{c}\text { according to the plan, } \\
\text { Codes of Good Practices) }\end{array}\end{array}$ & Completeness & $\begin{array}{c}\text { Number of missing } \\
\text { elements } \\
\text { Number of odd elements }\end{array}$ & $\begin{array}{c}\text { Number of missing } \\
\text { and odd elements } \\
\text { should be zero }\end{array}$ \\
\hline DIN EN 1990 & Load-bearing Resistance & $\begin{array}{c}\text { Load application time } \\
\text { Pressure, tension }\end{array}$ & $\begin{array}{c}\text { Resistance should be } \\
\text { maximized }\end{array}$ \\
\hline
\end{tabular}

These quality characteristics will be evaluated at previously defined control points (see Section 2.1) for retrospective assessment. For the quality assessment at the control points, measurable parameters are needed, such as the length of a component, in order to compare the actual values with the nominal values and to decide whether the criteria were met.

For predictive assessment, the quality will be propagated for the upcoming processes in order to make a prediction about the quality of the overall product. For instance, the variance-covariance propagation or the Monte-Carlo simulation can be used for the same quality parameters [46].

With these predicted parameters, the nominal can already be compared with the actual value at the time of computation, so the prediction can provide information for the decision points. However, this prediction does not replace the measurement, so that it can only be used as an aid for the decision. Nevertheless, a measurement should be done for the final nominal/actual comparison at the end of the process.

\subsection{Environmental Quality}

According to Johnson, "environmental quality" represents a measure of the condition of an environment relative to the requirements of one or more species and/or to any human need or purpose (1997) [47]. The specification of the fundamental definition can vary and depends on the context and the field of the application. In the context of LCA, environmental quality usually is related to the stability of environmental systems, grouped in areas of protection $[48,49]$. The method of LCA quantifies the potential damage of technical systems to these areas of protection through environmental impact assessment, following cause-effect chains and attributing anthropogenic activities to their potential destabilization of the earth's system. The method makes use of environmental impact assessment models characterizing the potential impact on elementary flows that pass the system boundary of the global anthropogenic system and optionally allows for normalization and aggregation [50,51]. While there are manifold environmental impact assessment methods and indicator frameworks available, there are only a few holistic approaches that aim to cover all relevant areas of protection (see Table 2) [49,52]. Among these, the planetary boundary framework is of special interest as it provides a safe operating space quantification on a global level for nine planetary boundaries developed within the interdisciplinary work of environmental experts on global biophysical systems and global resource stocks [53-56].

As the concept itself does not refer to LCA, there is an additional attribution necessary to make the planetary boundaries accessible for LCA. The Joint Research Centre (JRC) of the European Commission 
provides a normalization framework based on the planetary boundaries that allow for applying the planetary boundaries in the context of LCA and deriving single points on environmental quality. As all environmental impact assessment methods provide their characterization factors freely, this approach provides feedback on the impacts on the global environmental quality of any modelled system through an application on any LCA model.

Based on this information, a concept of environmental quality for Co-Design was developed. When applied in the specific context of Co-Design, LCA models have to be provided for all processes considered and materials relevant for the available design space and decision options. As for buildings where environmental quality is strictly related to building certifications, data requirements are thus defined by the systems considered and vice versa, as only systems with existing models can be assessed regarding their environmental quality.

Environmental quality requirements are requirements to the system with regard to its impact on environmental areas of protection derived from bio-geophysical system stability. The evaluation of environmental quality relies on quality characteristics and parameters. Quality characteristics are LCA-related impact categories addressing the areas of protection. Quality parameters represent Life Cycle Inventory values related to impact category through their respective characterization factors. Environmental quality criteria constitute the quantification of an environmental quality requirement under consideration of scientific findings and political requirements. Consequently, they define a maximum impact threshold (minimum quality) and/or a target value. The following Table 2 provides such definitions in the form of concrete examples for a better understanding. Based on, for example, the requirement of climate system stability (planetary boundaries), the Global Warming Potential (GWP) over 100 years is considered as quality characteristic. According to ISO 14040, ISO 14044, and EN 15804, the total emissions of carbon dioxide equivalent (due to $\mathrm{CO}_{2}$ and other greenhouse gas emissions) are evaluated as a quality parameter $\left(\mathrm{kg} \mathrm{CO}_{2}\right.$ eq.) the GWP. There are many examples available of political measures which try to identify and achieve a target value. One example is the political target of climate neutrality (net zero $\mathrm{CO}_{2}$ equivalents). In Switzerland, this has been derived based on a top-down benchmark of $1000 \mathrm{~kg} \mathrm{CO}_{2}$ equivalents per person and per year as further maximal impact threshold [57]. With an assumed living space of $45 \mathrm{~m}^{2}$ per capita, this would result in an impact of less than $6 \mathrm{~kg} \mathrm{CO}_{2}$ equivalents per $\mathrm{m}^{2}$ and year for residential buildings. For Germany, such a value has not been specified yet.

Table 2. Exemplary quality characteristics, parameters and criteria for environmental quality.

\begin{tabular}{|c|c|c|c|}
\hline Requirements & Quality Characteristic & Exemplary Parameters & Criteria \\
\hline $\begin{array}{l}\text { Climate system } \\
\text { stability }\end{array}$ & $\begin{array}{c}\text { Global warming Potential } \\
\text { (LCIA method IPCC, } 100 \\
\text { years) [58] }\end{array}$ & $\mathrm{kg} \mathrm{CO}_{2}$ eq. emitted & $\begin{array}{l}\text { Share of global warming potential } \\
\text { of the building should not exceed } \\
6 \mathrm{~kg} \mathrm{CO} \text { equivalents per } \mathrm{m} 2 \text { and } \\
\text { year derived from the impact each } \\
\text { person not exceeding (1000 kg } \\
\mathrm{CO}_{2} \text { equivalents per year) }\end{array}$ \\
\hline $\begin{array}{l}\text { Land-System } \\
\text { protection, } \\
\text { water-based } \\
\text { erosion resistance }\end{array}$ & $\begin{array}{c}\text { Erosion potential, } \\
\text { transformation (LCIA } \\
\text { method LANCA }{ }^{\circledR} \text { V2.5) [59] }\end{array}$ & $\begin{array}{l}\text { Area and type of } \\
\text { transformed patch of } \\
\text { land ( } \mathrm{x} \mathrm{m} 2 \text { transformed } \\
\text { from land use type A to } \\
\text { land use type } \mathrm{B})\end{array}$ & $\begin{array}{l}\text { Threshold based on Soil Quality } \\
\text { Index, Impact should be } \\
\text { minimized }\end{array}$ \\
\hline $\begin{array}{l}\text { Land-System } \\
\text { protection, } \\
\text { groundwater } \\
\text { regeneration }\end{array}$ & $\begin{array}{l}\text { Groundwater Regeneration } \\
\text { reduction potential, } \\
\text { transformation (LCIA } \\
\text { method LANCA }{ }^{\circledR} \text { V2.5) [59] }\end{array}$ & $\begin{array}{l}\text { Area and type of } \\
\text { transformed patch of } \\
\text { land ( } x \mathrm{~m} 2 \text { transformed } \\
\text { from land use type } A \text { to } \\
\quad \text { land use type } B)\end{array}$ & $\begin{array}{l}\text { Threshold based on Soil Quality } \\
\text { Index, Impact should be } \\
\text { minimized }\end{array}$ \\
\hline $\begin{array}{l}\text { Human health } \\
\text { protection }\end{array}$ & $\begin{array}{l}\text { Human toxicity, cancer } \\
\text { effects (LCIA method } \\
\text { UseTox } 2.0[60])\end{array}$ & $\begin{array}{l}\text { Chromium emissions to } \\
\text { agricultural soil }(\mathrm{kg}) \\
\text { Formaldehyde emissions } \\
\text { to air }(\mathrm{kg})\end{array}$ & $\begin{array}{l}\text { Disability-adjusted life years } \\
\text { (DALY) }\end{array}$ \\
\hline
\end{tabular}




\subsection{Social Quality}

Social quality is a complex concept that has received increasing attention in recent years, not least because SDGs have made it more important to take social needs into account on the path to sustainable development in general and in the context of buildings in particular. Some basic ideas will be presented on the concept of social quality in relation to buildings and construction processes and how this concept can be integrated into an HQM.

So far, social quality has not been integrated systematically into quality assessment models in the building sector. Approaches like Universal Design or Design for All [61] usually only refer to a particular aspect of social quality. In addition, model-based strategies of integrating sustainability and universal design aspects often come down to considering mainly cost expenditure [62]. On a policy level, social quality aspects of housing and urbanity have been addressed in the context of the UN sustainable development goals (SDGs) and the concept of social sustainability. Although social sustainability has become a prominent concept in sustainability policy discourse and literature, it is still found vague and undertheorized [63]. In particular, there is a lack of empirical and theoretical studies that specify the meaning of social quality and social sustainability for building construction and examine how social quality aspects can be integrated into the quality assessment of buildings and building processes. Therefore, the research presented in this article covers new and uncharted territory by, first, specifying social quality requirements for the building construction sector, and, second, integrating social quality, environmental and technical quality assessment into a holistic quality model, and, third, developing a (holistic) model of quality assessment for real-time quality assessment during the ongoing design and construction process, which is unparalleled in the field so far.

To do so, this understanding of social quality is based on social science literature in the field of technology assessment and social sustainability research, as well as relevant codifications and recommendations on social quality and sustainability pertaining to buildings on the national and international level. According to Grunwald, who understands (social) sustainability as an integrative concept that encompasses different dimensions, namely intra- and intergenerational justice, a global orientation, and an anthropocentric approach [64]. Those dimensions allow different substantial requirements to be formulated due to different normative positions. Further, a normative-functional concept of sustainability is presented by Renn. This means that social sustainability is both a normative concept that indicates a desirable state of the social world based on justice and individual quality of life and a functional one that indicates that basic functional requirements must be fulfilled to secure the lives of present and future generations [6]. Therefore, social sustainability can be seen as a condition for ensuring the functioning of society and technological innovations as well as a normative ideal constituted by the values of justice and human well-being. How these values are interpreted in a particular context may vary according to different normative and socio-cultural value systems and orientations. Social sustainability, in any case, encompasses the fair distribution of benefits and burdens on the way to a more sustainable future and thus forms a precondition for reconciling social demands and environmental sustainability [5]. Social sustainability thus also serves to create the conditions of acceptability for functional and environmental provisions to promote sustainability.

This normative-functional understanding of social sustainability can be applied to the concept of social quality in the context of buildings and construction processes. Like social sustainability, the concept of social quality also refers to the basic values of justice and fairness as well as well-being and the opportunity to participate in social life. Additionally, like social sustainability, social quality can be considered a prerequisite of technical functionality and environmental sustainability of buildings and construction processes. Firstly, because technical systems do not only become functional through their technology, but their functioning is also determined by their arrangement as socio-technical systems. Thus, the function and functionality of technologies are always dependent on their use, the users, their context and the associated social structures. Social structures and technological systems shape each other recursively [65]. Social quality and sustainability refer not only to the social impacts of technical systems but also to the effect of social structures on technical systems. Social quality thus 
aims to ensure fairness and functionality of socio-technical systems and thereby the acceptability of socio-technical systems.

In order to specify the requirements of such a normative-functional concept of social quality for the purposes of an HQM for buildings and construction processes, it can be drawn on established policies pertaining to matters of sustainability and construction, as formulated by international organizations, national governments, and national or international stakeholders.

In addition, expert discussions are useful to specify social quality requirements for the HQM that have not yet been explicitly and institutionally defined in the building context. Debates about human-machine-interaction, cyber-physical workspaces or future-proof Co-Design processes and products and socio-aesthetic requirements have gained significance in recent years. This is especially relevant for Co-Design processes and products, as can be seen by the comprehensive requirement analysis derived through the expert survey (see Section 2.2). Respondents in this survey considered not only conventional requirements, like work safety, well-being, and accessibility to be important, but also accountability and transparency in computational systems, participation in different phases of the construction process as well as usability of buildings.

Based on the social science literature, relevant policy documents and the expert survey in IntCDC, some exemplary requirements, characteristics and parameters of social quality are identified for the HQM in Table 3.

Table 3. Exemplary quality characteristics, parameters and criteria for social quality.

\begin{tabular}{|c|c|c|c|}
\hline Requirements & Quality Characteristic & Exemplary Parameters & Criteria \\
\hline \multirow{4}{*}{$\begin{array}{l}\text { Decent Work } \\
{[66,67]}\end{array}$} & \multirow{3}{*}{ Control Capacity } & $\begin{array}{l}\text { Possibility to set up own work } \\
\text { station [68] }\end{array}$ & \multirow{3}{*}{ Should be maximized } \\
\hline & & $\begin{array}{l}\text { Access to all relevant } \\
\text { information [69] }\end{array}$ & \\
\hline & & $\begin{array}{c}\text { Transparency of algorithmic } \\
\text { decision making [70] }\end{array}$ & \\
\hline & $\begin{array}{l}\text { (Re-) Configuration of } \\
\text { workforce and skills [71] }\end{array}$ & $\begin{array}{l}\text { Generation of new jobs, } \\
\text { demise of obsolete ones }\end{array}$ & $\begin{array}{l}\text { Creation of jobs for high and } \\
\text { low skilled workers }\end{array}$ \\
\hline \multirow{2}{*}{$\begin{array}{c}\text { Inclusiveness } \\
{[66,72]}\end{array}$} & Accessibility [73] & $\begin{array}{l}\text { Barrier-free access to all usage } \\
\text { units for diverse groups of } \\
\text { population }\end{array}$ & Should be high/ given \\
\hline & $\begin{array}{c}\text { Adaptable } \\
\text { usability/flexibility [74] }\end{array}$ & $\begin{array}{l}\text { Conversion potential of } \\
\text { buildings: Percentage of } \\
\text { support-free floor plants }\end{array}$ & Should be maximized \\
\hline \multirow{3}{*}{$\begin{array}{l}\text { Socio-cultural and } \\
\text { functional quality } \\
{[72,75,76]}\end{array}$} & $\begin{array}{c}\text { Building culture } \\
\text { diversity/aesthetic } \\
{[76,77]}\end{array}$ & \multirow{2}{*}{$\begin{array}{l}\text { Public and/or expert } \\
\text { evaluation [76] }\end{array}$} & \multirow[t]{2}{*}{ Evaluation carried out } \\
\hline & $\begin{array}{c}\text { Urban development } \\
\text { quality }[76,77]\end{array}$ & & \\
\hline & Wellbeing [78] & $\begin{array}{l}\text { Public spaces in the } \\
\text { building [77] }\end{array}$ & $\begin{array}{l}\text { Number of areas and number } \\
\text { of seats available in relation to } \\
\text { number of users should be } \\
\text { maximized [79] }\end{array}$ \\
\hline
\end{tabular}

Social quality refers to buildings and construction processes and their respective capacity to enable social justice and a good life for a diverse workforce and user community. Social quality thus concerns work processes in construction and the built spaces (the buildings) which (materially) structure social life for the users. In this respect, the consideration is limited to the relevant structures and their dynamics to buildings and construction processes as socio-technical systems that are subject to decision making in and by the construction process.

Whether a certain matter is subject to decision-making in the construction process is a central criterion for including its social characteristics in the HQM. While certain aspects, such as social 
security legislation, and the quality of the surrounding infrastructures, such as public transport, are not subject to decision-making by the actors involved in construction, others are, such as usage of technology, company-based competence development or creating inclusive working conditions and inclusive built spaces.

Thus, requirements are included which refer to subjects of decision-making by the actors involved in construction processes. The requirements that are taken into account are based on known relationships between the character of the socio-technical construction processes and buildings and decision making which are considered relevant by public and expert discourses.

Based on these requirements, characteristics for social quality can be identified and operationalized and parameters can be derived from them which allow for the comparison between the desirable socio-technical configurations, which act as target values, and the actual socio-technical configuration. While a numerical assessment of those configurations is generally not possible (what would, for instance, be the double amount of access to relevant information?), different categorical stages of a purely qualitative parameter (not quantitative) can be formulated, like high-mid-low, ranked and used to evaluate how close the actual state gets to the target.

\section{Results}

\subsection{Co-Design in Construction}

As the current state-of-the-art research mainly aims to improve single aspects, innovation remains incremental and fragmented. Co-Design aims to harness the full potential of digitalisation through an integrative non-linear construction process based on computational feedback loops. The HQM will support the integrative construction processes and provide the basis to control feedback loops.

Figure 4 illustrates the integration of holistic quality assessment in the innovative Co-Design construction process. In contrast to the linear construction process, the Co-Design construction process is non-linear and integrative. There are computational feedback loops between planning and execution, and the process is no longer sequential.

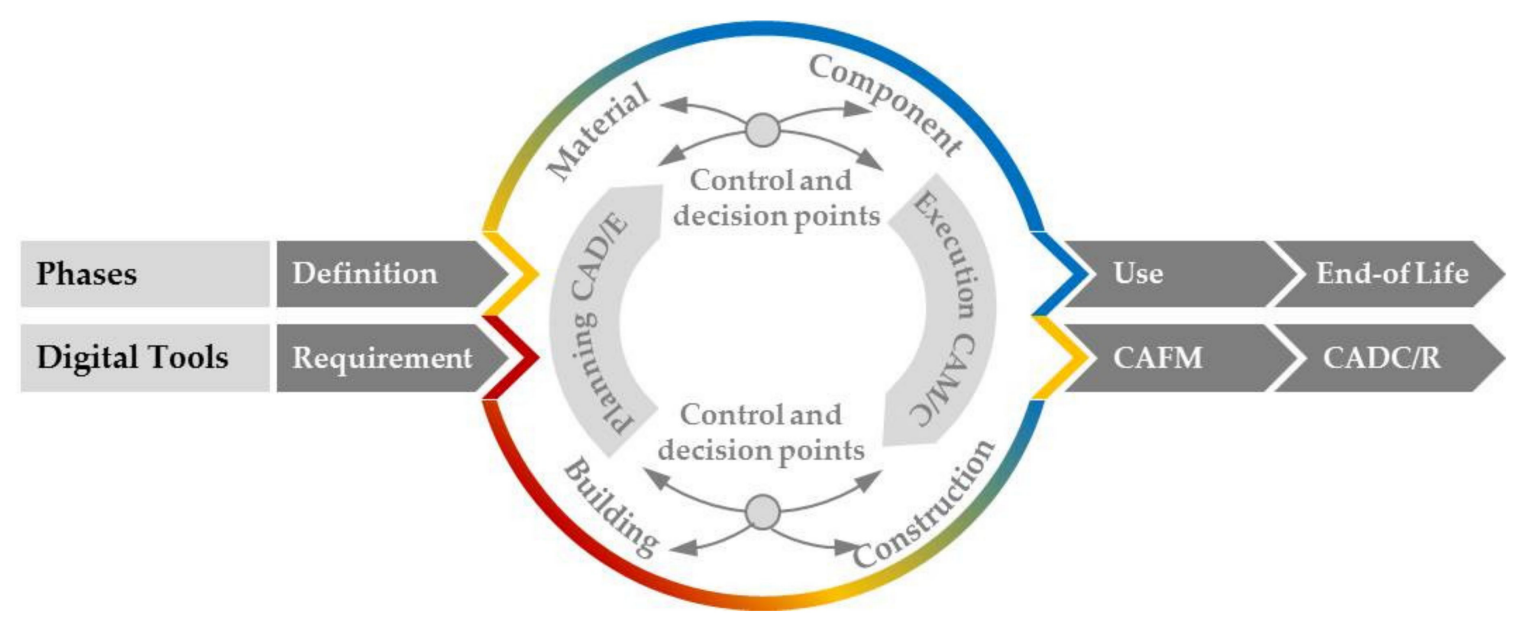

Figure 4. Holistic quality assessment in the Co-Design construction process.

Furthermore, the current approaches are mainly based on the digitalisation of already existing construction processes and materials; whereas in IntCDC, the novel, sustainable and adaptable materials and Co-Design processes and products are not established yet, which is the challenge.

To support the Co-Design approach, the Co-Design processes and products are broken into four levels of hierarchy of building: building, construction, component and material [80], since a building consists of several constructions, which in turn consist of several components made of different materials. These levels of hierarchy have their products and the associated processes. 
In addition, the order in which the individual levels of hierarchy are run through differs in planning and execution. In the planning phase, planners can define only a few fundamental aspects, i.e., building type, the required area, the construction type (e.g., lightweight, hybrid or concrete construction) and the energy standard required. Then constructions can be examined regarding the insulation required or the materials used. Afterwards, the planner can design the construction in detail, by choosing components and the manufacturing process required. For this purpose, the connecting elements required, such as screws, are included, in addition to the individual components. Finally, the individual materials required for the building components are considered.

In the execution phase, the levels of hierarchy work in reverse order to the planning phase. Here, the workers start with the acquisition and processing of the materials, before the individual components are manufactured from them. These components are assembled to form constructions and, finally, are assembled in the buildings.

In the Co-Design processes and products, the integration of the planning and execution occurs on different levels of hierarchy, from novel, sustainable materials up to the complete Co-Design processes and products.

As introduced in Section 2.1, the HQM, which contains quality characteristics and parameters can be applied for holistic quality assessment. The different technical, environmental, and social processand product-related quality characteristics and parameters are assigned to each of these construction phases and levels of hierarchy of the construction process by using the control and decision points. In this way, the quality of the Co-Design construction process phases and levels of hierarchy can be assessed in a holistic and systematic way.

In this approach, the results of the holistic quality assessment will be used as a basis for decisions for the further construction process and aim to detect problems at an early stage and estimate their impact on the overall building. It allows the model user to foresee the effects of their decisions and project the effects with regard to the complexity of the entire building life cycle. However, because of the novelty and non-linearity of the construction process, some of the connections between the phases and levels of hierarchy are still unknown, which makes the prediction of their impact in the future challenging or limited. Moreover, the quality assessment or prediction is not only based on the respective quality characteristics and parameters but also includes the interrelations with other quality characteristics, which can make the prediction and decision even more challenging.

\subsection{Holistic Quality Model Setup}

The technical, environmental, and social quality of Co-Design processes and products are introduced in Sections 2.2-2.4, the interrelations between these are used for the integration of the three aspects in HQM.

While on-site construction is still mainly a manual process, IntCDC will integrate semi- and fully automated construction processes using intelligent machines (e.g., cranes) and robot systems. Therefore, the changing socio-technical arrangement (the relationship between social and technical structures), e.g., in the form of human-machine-interfaces, and changed environmental impacts, e.g., due to digitalisation and automation as well as novel materials, are essential parts of the object that will be considered systematically. Furthermore, the novel production process, e.g., how the products are fabricated, constructed and assembled and how the quality characteristics interrelate need to be understood. Figure 5 shows the setup of the HQM with the interrelations between technical, environmental and social quality. There are interrelations and overlaps between two aspects, as well as between all three aspects when setting up the HQM. Typical performance parameters in the HQM and examples for overlaps and interrelations will be outlined. 


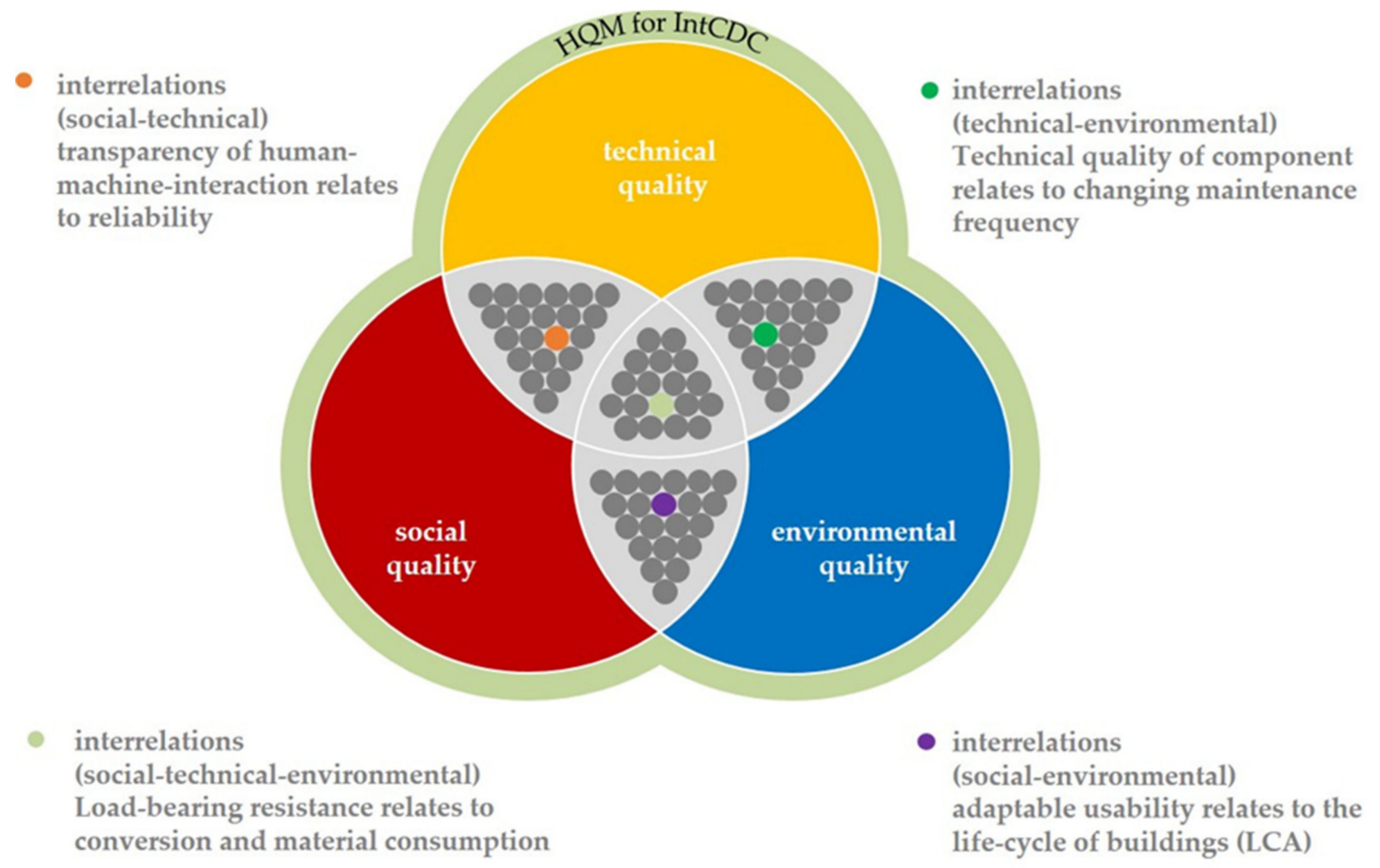

Figure 5. HQM setup with exemplary interrelations among technical, environmental and social quality.

The technical quality of processes and the related technical product quality constitute the reference flow and the functional equivalent as an integral part of the environmental quality. Furthermore, each of the processes investigated causes direct and indirect environmental impacts and thus influences all the environmental quality characteristics. Products, as a result of a process chain, are the aggregate of the quality characteristics of all processes in relation to the functional equivalent, or the technical product quality of a building. When, for instance, the technical quality influences the service life of components such as the fatigue strength of a beam, resulting in changing the maintenance frequency, the environmental quality is directly affected (shown as an example in the upper right of Figure 5). This change in environmental quality can be investigated through prediction of component service life.

For an example of a social quality requirement and its interrelation with technical quality, the case of decent work here is used. Decent work requires fairness and a guarantee of fundamental rights. It refers, among other things, to the workers' control capacity in the form of being able to influence and configure options, training and development opportunities, organization of working times, physical and psychological job requirements, work intensity, and employment security [68]. Since the Co-Design construction process is supposed to include a high proportion of computational and robotic processes, quality characteristics that refer to the nature of automated processes, such as transparency and access to relevant information, are particularly relevant. They refer to the workers' chances of understanding their work, making responsible decisions and participating in shared control in human-machine-interaction instead of just carrying out tasks based on machine instructions. Transparency, access to information, and shared control, in turn, require training and open up scope for action and personal development, thus enabling meaningful work. At the same time, this increases the resilience of technological processes [81] and, thus, technical quality, especially with regard to reliability. This is shown in the upper left of Figure 5.

Inclusiveness is a crucial social quality requirement for all buildings. Inclusiveness means that the building enables equitable access and usage by a diversity of users according to their needs, without excluding or marginalizing certain groups. Two important characteristics that can be derived from this requirement are accessibility and adaptable usage or flexibility. Accessibility has become a well-accepted standard that describes buildings which can be found, accessed and used by people 
with disabilities on an equal basis with others, in the generally customary manner without particular difficulty, and, in principle, without outside help [82]. The concept of adaptable use is still less common. It means that buildings are designed to be as flexible as possible and that the greatest possible conversion capacity is provided for [74]. Adaptable use enables people with a variety of different lifestyles or special needs to find housing or stay in their houses and adapt them to their needs when life circumstances change, for instance in later life. An example for the interrelation between social and environmental quality characteristics can be found in Figure 5, bottom right. The potential for conversion, which is a prerequisite for adaptable use, is strongly related to the technical implementation of the building concept; it extends the life of the building and is therefore strongly related to LCA [74].

A simplified example referring to load-bearing resistance may illustrate some interrelations between the three aspects of quality (as shown in Figure 5, bottom left). While load-bearing resistance is a genuine technical quality characteristic for the performance of the building, it is also directly associated with social quality and, indirectly, with environmental quality. Load-bearing resistance influences the social quality of the building in that it affects the conversion potential and, therefore, the flexibility of the building in terms of adaptable use. Even if load-bearing resistance may not have a direct impact on the environmental quality of the building itself, higher loadbearing resistance may mean higher material consumption and thus have an impact on the environmental quality of the production process. However, the interrelations cannot be understood as shared criteria. While technical quality criteria require a certain degree of load-bearing resistance, social quality criteria may require a higher load-bearing resistance with regard to possible future conversion. At the same time, in simplified terms, increased material consumption for a higher load-bearing resistance can also have a detrimental environmental impact and would therefore be contrary to environmental quality criteria. This means that different quality criteria may compete with each other and that conflicting objectives may arise. There cannot be a "perfect" building that meets all the requirements at the same time. The HQM and holistic quality assessment cannot always provide a "perfect" solution for such conflicts, but they provide a means to make them visible and manage them in a deliberate and responsible manner.

\subsection{Exemplification}

The HQM will be explained based on the example of semi-robotic production of gradient concrete slabs in IntCDC. It will be explained how the three quality aspects interact and what the relevance of control and decision points is in order to discuss the holistic quality assessment of building components and construction processes.

The purpose of semi-robotic production is to produce the required components as precisely as required according to the requirements of the planning like a given size and a defined load-bearing resistance, while taking into account the interaction between human and machine.

Here, the HQM needs to consider various defined properties and requirements of a concrete slab. Human-machine-interaction plays an important role here, as smooth interaction and communication between humans and machines can significantly influence the quality of the production process and the products. Furthermore, the concrete slab should have a certain technical size and, for the intended robustness, a predefined load-bearing resistance is required.

The lower part of Figure 7 shows the interrelations between the quality characteristics. Considering the process in Figure 6, human-machine-interaction influences the reliability of a production process, which in turn influences the timeliness. The total duration of production also influences the amount of energy required, which is higher in the case of many interruptions because of faults, as the machines are in use longer. This also directly impacts environmental quality characteristics, such as the energy consumption effects and global warming potential (GWP). Regarding GWP, next to direct process-related energy, the energy-related impacts of the cement production process (mainly the clinker production) and the direct process-related carbon dioxide emissions from carbonization are relevant. In addition to this, since energy intensity due to clinker production represents the highest share, particular attention is currently given to a possible reduction in the material by especially 
reducing the clinker-to-cement ratio. This simultaneously has an effect on the product. Furthermore, the application of additives may directly impact human health. In addition, depending on how the human-machine-interface is designed, different degrees of accuracy can be achieved.

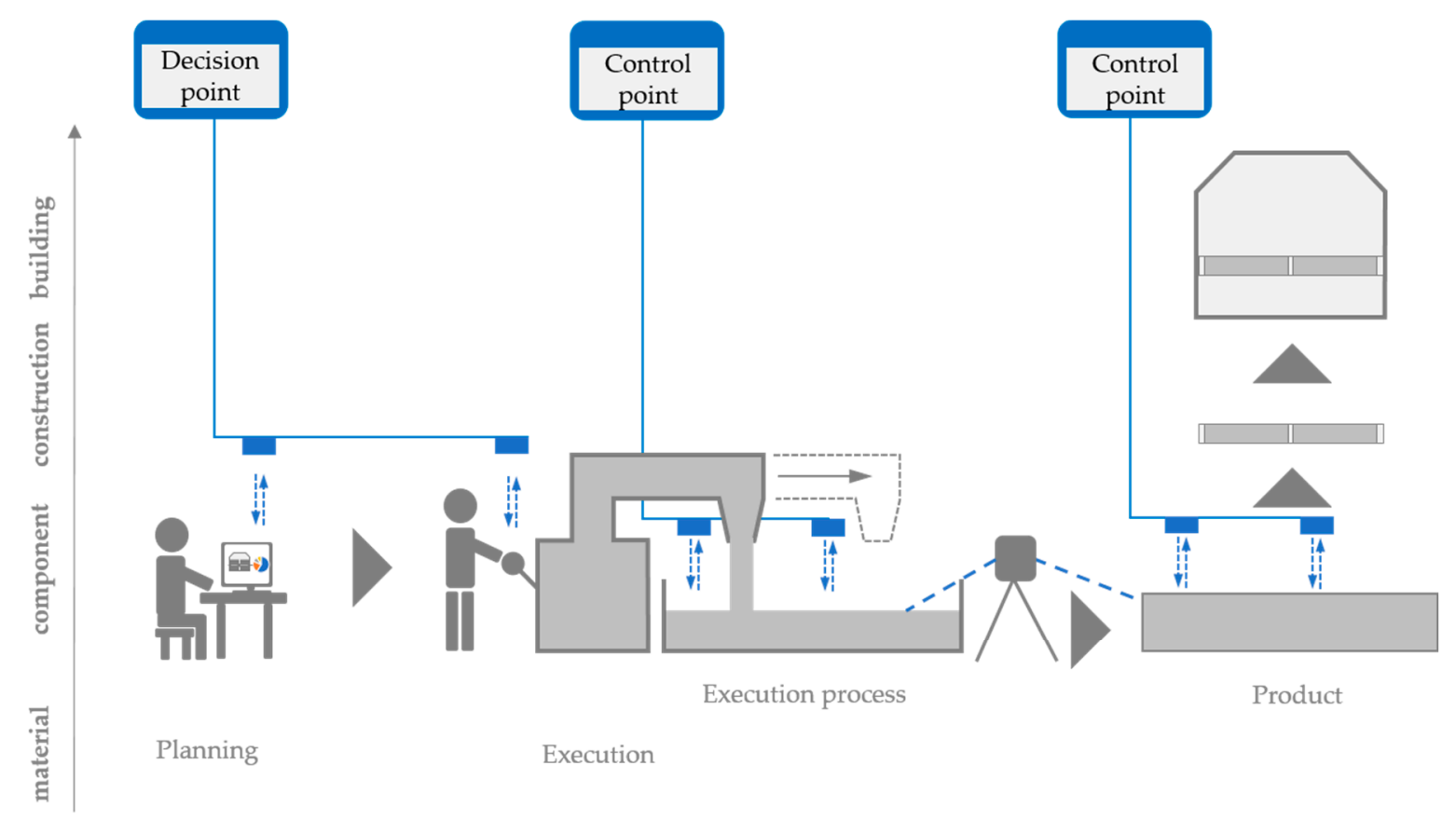

Figure 6. Process, decision and control points for semi-robotic production of concrete slabs with hollow spheres.

Quality characteristics are identified for all three quality aspects. In compliance with the HQM, process- and product-related quality characteristics are analysed, as shown in Figure 7 . The production and the component are shown with exemplary quality characteristics and their connections in Figure 7. The quality assessment of this concrete slab is divided into an assessment of the production process and an assessment of the concrete slab itself (product) including foreseeable implications for the future. 


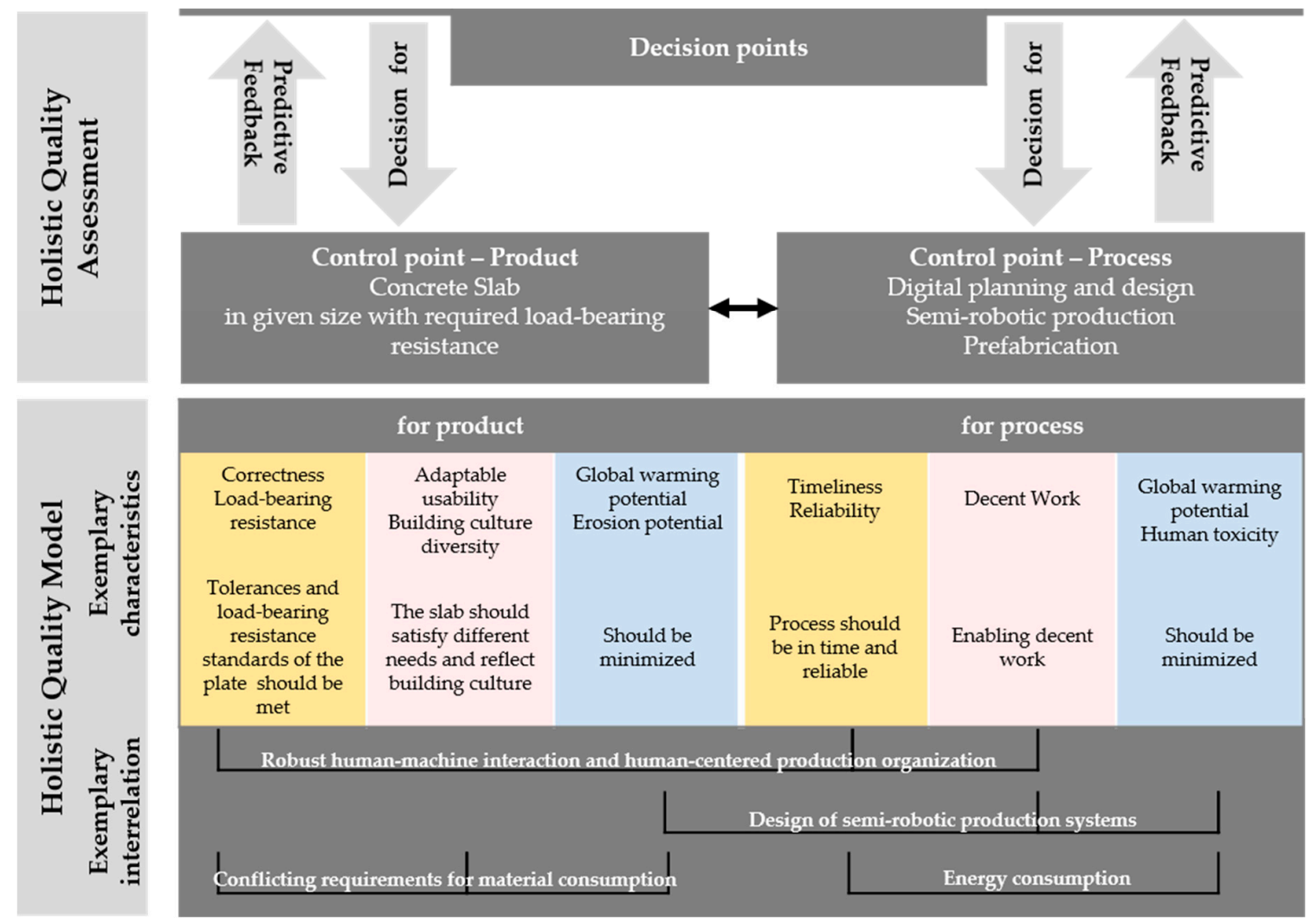

Figure 7. Holistic quality model and assessment for semi-robotic production of the concrete slab with hollow spheres.

For the product itself, the correctness of the component, in this case, the tolerances of the dimensions of the component itself and the flatness of the component, influences the load-bearing resistance of the component. From an environmental point of view, reducing the material and clinker quantities, on the one hand, decreases the $\mathrm{CO}_{2}$ emissions, and thus the GWP, but, on the other hand, it may affect the load-bearing resistance and thus require more material to meet the design requirements (and higher impacts accordingly). Furthermore, changes in concrete admixtures regarding sand and gravel content will have an impact on soil erosion potential due to open-pit mining activities in the upstream chain. The load-bearing resistance of the building component and the material properties are of great importance for possible conversion in the future and for the effects on the service life of the building.

For quality assessment, one decision point and two control points are defined as an example. The production incorporates a decision point specifying the product and process design. One control point is for the assessment of the process, and one for that of the product.

At the decision point, the planner chose the concrete admixtures, as well as the production process. These decisions directly affect technical, environmental and social quality aspects. The choice of additives in the mixture not only influences the concrete behaviour during the production process and, thus, the technical product quality, but also influences the environmental quality, as the admixtures have different environmental impacts. Furthermore, as the admixture choice might also limit process options, the working environment and corresponding social quality will be affected. To support the decision, a predictive quality assessment investigates the influence of the decision options at control points and provides quality feedback on the potential outcomes of decisions. The outcomes of the decisions made can be checked at the control point through quality measurement.

The two quality evaluations of the component, during and after the production process, can be defined as two control points. The worker can firstly take measurements during the production process 
using a Terrestrial Laser Scanner (TLS), which can be defined as one control point of the process. For example, TLS can measure the position of embedded elements (e.g., reinforcement) in the concrete slab during production process. By comparing the measured positions with the nominal positions of the embedded elements and the tolerance, the worker can obtain information and decide whether the production process has to be adapted or not, because inaccuracy position of the embedded elements affect the load-bearing resistance negatively. This control point allows for real-time quality control that is integrated into the process.

Furthermore, as a control point of the product, after the prefabrication of the concrete slab, the worker can use the TLS to measure the flatness and the size of the concrete slab and check if the deviation to the nominal value is within the tolerance so that this slab can be used for assembly later on. In this way, the worker is able to detect a lack of quality at an early stage.

This simplified example will be used to show how different characteristics relate to each other. It shows how the quality characteristics of the individual products or processes can be assessed, but also the interrelations between them and their impact on other life cycle phases. With this information, the far-reaching effects of seemingly banal decisions can be made visible and considered in planning. The next step of the quality model setup will be to determine the direction of the relationship between the different characteristics. For example, the load-bearing resistance measured at a control point influences the conversion potential and the LCA in opposite directions. While a higher bearing resistance can positively influence the future conversion potential of the building, it has a negative effect on resource consumption and, thus, on emissions. Information on these potential impacts must be provided at the relevant decision point in order to be able to balance the different quality characteristics.

\section{Summary and Outlook}

As part of IntCDC, which aims to make a significant contribution to establishing a high-quality and more sustainable building industry, a quality assurance concept for Co-Design processes and products was developed. This quality assurance concept consists of an HQM that enables holistic modelling of the quality and a holistic quality assessment which realizes the quality evaluation by using control and decision points.

The focus of this paper is the setup of the HQM. First, the technical, environmental, and social quality aspects are described. Up to now, there are no quality models that consider and integrate all these three aspects throughout the life cycle of buildings. Based on disciplinary requirement analyses, quality characteristics, parameters, and criteria are outlined exemplarily. The main challenge is the integration of the three quality aspects into one HQM. Therefore, the focus was on the interrelations between the three quality aspects. For quality assessment, the control and decision points serve not only to assess the quality at a certain point in time but also to predict the effects of the decision at these points throughout the entire life-cycle of the building in order to enable sustainable decision-making. The interrelations between the quality characteristics and the control and decision points were shown exemplarily for this production process. Furthermore, the levels of hierarchy are defined to support the Co-Design approach.

As the HQM is application-oriented, an investigation and concretization of quality characteristics, parameters, and criteria are needed, as well as their interrelations for different processes and products: for example, for the novel timber construction and long-span fibre-composite construction. The challenge and focus of this work will be the integration of the three aspects. In addition, if the production process changes, the HQM and quality assessment should also be adapted: For example, the production of concrete slabs could be fully automatic in the future. This approach would, for instance, change human-machine-interaction and affect the different quality characteristics and their interrelations.

Furthermore, the control and decision points also need to be defined for different processes and products in different construction phases and levels of hierarchy. It will be challenging, due to the novel non-linear and integrative construction process. The design of the decision points is currently 
especially problematic. The major challenge here is that the Co-Design approach is still in development. Therefore, it is not yet possible to establish when, and by which actor, decision points will be used.

Author Contributions: L.Z., L.B. and V.S., have developed and written the technical quality-related Section 2.2; R.H., R.D.B. and P.L., have developed and written the environmental quality related Section 2.3; D.H., K.B. and C.K., have developed and written the social quality-related Section 2.4; All the authors have developed and jointly written sections on the HQM setup and example (Sections 3.2 and 3.3). D.H. and K.B., have written the sections on Co-Design: scope and ambition, and research gap and hypothesis (Sections 1.1 and 1.4); L.Z. and L.B., have written the section state of the art of construction process (Section 1.2), the section on the general definition and quality assurance concept (Section 2.1), the IntCDC Co-Design construction process (Section 3.1), as well as the summary and the outlook (Section 4); R.H. and R.D.B., have written the section on sustainability in the construction sector (Section 1.3). All authors have read and agreed to the published version of the manuscript.

Funding: The research published in this article is supported by the Deutsche Forschungsgemeinschaft (DFG, German Research Foundation) under Germany's Excellence Strategy-EXC 2120/1-390831618. The authors cordially thank the DFG.

Conflicts of Interest: The authors declare no conflict of interest.

\section{References}

1. Global Alliance for Buildings and Construction; International Energy Agency and the United Nations Environment Programme. 2019 Global Status Report for Buildings and Construction: Towards a Zero-Emission, Efficient and Resilient Buildings and Construction Sector. 2019. Available online: https://www.worldgbc.org/news-media/2019-global-status-report-buildings-and-construction (accessed on 22 September 2020).

2. United Nations. World Population Prospects 2019: Highlights. Available online: https://population.un.org/ wpp/Publications/Files/WPP2019_10KeyFindings.pdf (accessed on 22 September 2020).

3. United Nations. World Urbanization Prospects: The 2018 Revision: Key Facts. Available online: https: //population.un.org/wup/Publications/Files/WUP2018-KeyFacts.pdf (accessed on 22 September 2020).

4. Moir, E.; Moonen, T.; Clark, G. What are Future Cities? Origins, Meanings and Uses. In Compiled by the Business of Cities for the Foresight Future of Cities Project and the Future Cities Catapult; Government Office for Science: London, UK, 2014.

5. Opielka, M. Soziale Nachhaltigkeit aus soziologischer Sicht. Soziologie 2016, 45, 33-46.

6. Renn, O.; Jager, A.; Deuschle, J.; Jehle, W.W. A normative-functional concept of sustainability and its indicators. Int. J. Glob. Environ. Issues 2009, 9, 291. [CrossRef]

7. Schweitzer, J.; Schwieger, V. Modeling of quality for engineering geodesy processes in civil engineering. J. Appl. Geod. 2011, 5. [CrossRef]

8. Berner, F.; Kochendörfer, B.; Schach, R. Baubetriebsplanung, 2., [Aktualisierte] Aufl. Leitfaden des Baubetriebs und der Bauwirtschaf; Springer Vieweg: Wiesbaden, Germany, 2013.

9. World Economic Forum. Shaping the Future of Construction. A Breakthrough in Mindset and Technology; Prepared in Collaboration with the Boston Consulting Group. 2016. Available online: http://www3.weforum. org/docs/WEF_Shaping_the_Future_of_Construction_full_report_.pdf (accessed on 22 September 2020).

10. Berner, F.; Kochendörfer, B.; Schach, R. Grundlagen der Baubetriebslehre 3: Baubetriebsführung, 2. Aufl. Leitfaden des Baubetriebs und der Bauwirtschaft; Springer Vieweg: Wiesbaden, Germany, 2015.

11. Charef, R.; Emmitt, S.; Alaka, H.; Fouchal, F.; Foucha, F. Building Information Modelling adoption in the European Union: An overview. J. Build. Eng. 2019, 25, 100777. [CrossRef]

12. GhaffarianHoseini, A.; Tookey, J.; GhaffarianHoseini, A.; Naismith, N.; Azhar, S.; Efimova, O.; Raahemifar, K. Building Information Modelling (BIM) uptake: Clear benefits, understanding its implementation, risks and challenges. Renew. Sustain. Energy Rev. 2017, 75, 1046-1053. [CrossRef]

13. Ismail, N.A.A.; Chiozzi, M.; Drogemuller, R. An overview of BIM uptake in Asian developing countries. AIP Conf. Proc. 2017, 1903, 80008.

14. Lim, E.C.; Alum, J. Construction productivity: Issues encountered by contractors in Singapore. Int. J. Proj. Manag. 1995, 13, 51-58. [CrossRef]

15. European Commission. European Construction Sector Observatory: Country Profile Germany. 2018. Available online: https:/ec.europa.eu/docsroom/documents/40681/attachments/1/translations/en/renditions/ native (accessed on 9 April 2020). 
16. Ness, D.A.; Xing, K. Toward a Resource-Efficient Built Environment: A Literature Review and Conceptual Model. J. Ind. Ecol. 2017, 21, 572-592. [CrossRef]

17. Zafrilla, J.E.; López, L.A. Chapter 2-Booming and Stagnation of Spanish Construction Sector Through the Extended Carbon Footprint Concept. In Environmental Carbon Footprints: Industrial Case Studies; Muthu, S.S., Ed.; Butterworth-Heinemann an Imprint of Elsevier: Oxford, UK, 2018; pp. 19-43.

18. Jong, M.; de Henry, W.P.; Stansbury, N. Eliminating Corruption in Our Engineering/Construction Industry. Leadersh. Manag. Eng. 2009, 9, 105-111. [CrossRef]

19. Vanclay, F.; Esteves, A.M.; Aucamp, I.; Franks, D.M. Social Impact Assessment: Guidance for Assessing and Managing the Social Impacts of Projects; International Association for Impact Assessment: Fargo, ND, USA, 2015.

20. Ceranic, B.; Markwell, G.; Dean, A. 'Too Many Empty Homes, Too Many Homeless'—A Novel Design and Procurement Framework for Transforming Empty Homes through Sustainable Solutions. Energy Procedia 2017, 111, 558-567. [CrossRef]

21. United Nations. Transforming Our World: The 2030 Agenda for Sustainable Development. 2015. Available online: https://sustainabledevelopment.un.org/post2015/transformingourworld (accessed on 22 September 2020).

22. World Green Building Council. Green Building \& the Sustainable Development Goals. 2017. Available online: https://www.worldgbc.org/green-building-sustainable-development-goals (accessed on 2 June 2020).

23. Weidema, B.; Goedkoop, M.; Mieras, E. Making the SDGs Relevant to Business. 2018. Available online: https://www.lifecycleinitiative.org/new-project-linking-the-un-sustainable-development-goals-tolife-cycle-impact-pathway-frameworks/ (accessed on 2 June 2020).

24. UNEP-SETAC Life Cycle Initiative. In Towards a Life Cycle Sustainability Assessment: Making Informed Choices on Products; UNEP-SETAC Life Cycle Initiative: Paris, France, 2012. Available online: https: //www.lifecycleinitiative.org/wp-content/uploads/2012/12/2011\%20-\%20Towards\%20LCSA.pdf (accessed on 9 April 2020).

25. Vezzoli, C.; Ceschin, F.; Osanjo, L.; M’Rithaa, M.K.; Moalosi, R.; Nakazibwe, V.; Diehl, J.C. Design for Sustainability: An Introduction. In Designing Sustainable Energy for All: Sustainable Product-Service System Design Applied to Distributed Renewable Energy; Vezzoli, C., Ceschin, F., Osanjo, L., M'Rithaa, M.K., Moalosi, R., Nakazibwe, V., Diehl, J.C.1., Eds.; Springer: Cham, Switzerland, 2018; pp. 103-124.

26. Eberl, S. DGNB vs. LEED: A comparative analysis. In Central Europe Towards Sustainable Building; Petr, H., Jan, T., Antonín, L., Jan, R., Kateřina, S., Hájek, P., Tywoniak, J., Eds.; Extended Proceedings CESB10 Prague Conference; CESB: Prague, Czech Republic, 2010.

27. Deutsche Gesellschaft für Nachhaltiges Bauen. DGNB System Version 2018. 2008. Available online: https://www.dgnb-system.de/en/system/version2018/ (accessed on 9 April 2020).

28. Hollberg, A.; Genova, G.; Habert, G. Evaluation of BIM-based LCA results for building design. Autom. Constr. 2020, 109, 102972. [CrossRef]

29. Di Bari, R.; Jorgji, O.; Horn, R.; Gantner, J.; Ebertshäuser, S. Step-by-step implementation of BIM-LCA: A case study analysis associating defined construction phases with their respective environmental impacts. IOP Conf. Ser. Earth Environ. Sci. 2019, 323, 12105. [CrossRef]

30. Horn, R.; Ebertshäuser, S.; Di Bari, R.; Jorgji, O.; Traunspurger, R.; Von Both, P. The BIM2LCA Approach: An Industry Foundation Classes (IFC)-Based Interface to Integrate Life Cycle Assessment in Integral Planning. Sustainability 2020, 12, 6558. [CrossRef]

31. Deutsches Institut für Normung e.V. DIN EN ISO 9000:2015-11, Qualitätsmanagementsysteme_-Grundlagen und Begriffe (ISO_9000:2015); Deutsche und Englische Fassung EN_ISO_9000:2015; Beuth Verlag: Berlin, Germany, 2015.

32. Ortega, M.; Pérez, M.; Rojas, T. Construction of Systemic Quality Model or evaluation a Software Product. Softw. Qual. J. 2003, 11, 219-242. [CrossRef]

33. Niemeier, W. Ausgleichungsrechnung: Statistische Auswertemethoden; De Gruyter Lehrbuch; De Gruyter: Tubingen, Germany, 2008.

34. Wiltschko, T. Sichere Information Durch Infrastrukturgestützte Fahrerassistenzsysteme zur Steigerung der Verkehrssicherheit an Straßenknotenpunkten. Master's Thesis, Institute of Engineering Geodesy Universität Stuttgart, Stuttgart, Germany, 2004 
35. Zhang, L.; Schwieger, V. Real Time Quality Assurance Indexes for Residential House Construction Processes; FIG Working Week: Marrakech, Morocco, 2001; Volume 18.

36. Chen, L.; Luo, H. A BIM-based construction quality management model and its applications. Autom. Constr. 2014, 46, 64-73. [CrossRef]

37. Deutsches Institut für Normung e.V. DIN 18202:2013-04, Toleranzen im Hochbau_-Bauwerke; Beuth Verlag: Berlin, Germany, 2013.

38. Deutsches Institut für Normung e.V. DIN 4109-1:2018-01, Schallschutz im Hochbau_-Teil_1: Mindestanforderungen; Beuth Verlag: Berlin, Germany, 2018.

39. Deutsches Institut für Normung e.V. DIN EN 1995-1-1:2010-12, Eurocode_5: Bemessung und Konstruktion von Holzbauten_-Teil_1-1: Allgemeines_-Allgemeine Regeln und Regeln für den Hochbau; Deutsche Fassung EN_1995-1-1:2004_+AC:2006_+A1:2008; Beuth Verlag: Berlin, Germany, 2008.

40. Deutsches Institut für Normung e.V. DIN EN 1995-1-1/NA:2013-08, Nationaler Anhang_-National festgelegte Parameter_-Eurocode_5: Bemessung und Konstruktion von Holzbauten_-Teil_1-1: Allgemeines_-Allgemeine Regeln und Regeln für den Hochbau; Beuth Verlag: Berlin, Germany, 2013.

41. Deutsches Institut für Normung e.V. DIN EN ISO 286-1:2019-09, Geometrische Produktspezifikation_(GPS)_ISO-Toleranzsystem für Längenmaße_-Teil_1: Grundlagen für Toleranzen, Abmaße und Passungen (ISO_286-1:2010_+ Cor_1:2013); Deutsche Fassung EN_ISO_286-1:2010_+ AC:2013; Beuth Verlag: Berlin, Germany, 2013.

42. Deutsches Institut für Normung e.V. DIN EN ISO 9001:2015-11, Qualitätsmanagementsysteme_-Anforderungen (ISO_9001:2015); Deutsche und Englische Fassung EN_ISO_9001:2015; Beuth Verlag: Berlin, Germany, 2015.

43. Deutsches Institut für Normung e.V. DIN EN 1990:2010-12, Eurocode: Grundlagen der Tragwerksplanung; Deutsche Fassung EN_1990:2002_+ A1:2005_+ A1:2005/AC:2010; Beuth Verlag: Berlin, Germany, 2010.

44. McKenzie, W.M.C.; Zhang, B. Design of Structural Timber: To Eurocode 5, 2nd ed.; (Online-Edition); EBL-Schweitzer; Palgrave Macmillan: Basingstoke, UK, 2007.

45. Balangé, L.; Zhang, L.; Schwieger, V. First Step Towards the Technical Quality Concept for Integrative Computational Design and Construction. In Contributions to International Conferences on Engineering Surveying; Kopáčik, A., Kyrinovič, P., Erdélyi, J., Paar, R., Marendić, A., Eds.; Springer International Publishing: Cham, Switzerland, 2020; (in print). [CrossRef]

46. Schweitzer, J.; Schwieger, V. Modeling and Propagation of Quality Parameters in Engineering Geodesy Processes in Civil Engineering. In The 1st International Workshop on the Quality of Geodetic Observation and Monitoring Systems (QuGOMS'11); Kutterer, H., Seitz, F., Alkhatib, H., Schmidt, M., Eds.; Springer International Publishing: Cham, Switzerland, 2015; Volume 140, pp. 163-168.

47. Johnson, D.L.; Ambrose, S.H.; Bassett, T.J.; Bowen, M.L.; Crummey, D.E.; Isaacson, J.S.; Lamb, P.; Saul, M.; Winter-Nelson, A.E.; Johnson, D.N. Meanings of Environmental Terms. J. Environ. Qual. 1997, 26, 581-589. [CrossRef]

48. UNEP—SETAC Life Cycle Initiative. Global Guidance on Environmental Life Cycle Impact Assessment Indicators. Int. J. Life Cycle Assess. 2016, 21, 429-442. [CrossRef]

49. Rockström, J.; Steffen, W.; Noone, K.; Persson, Å; Chapin, F.S., III; Lambin, E.; Lenton, T.M.; Scheffer, M.; Folke, C.; Schellnhuber, H.J.; et al. Planetary Boundaries: Exploring the Safe Operating Space for Humanity. Ecol. Soc. 2009, 14. [CrossRef]

50. International Organization for Standardization Umweltmanagement-Ökobilanz-Grundsätze und Rahmenbedingungen DIN EN ISO 14040:2006. Available online: https://www.beuth.de/de/norm/dinen-iso-14040/122442325 (accessed on 22 September 2020).

51. Jolliet, O.; Muller-Wenk, R.; Bare, J.; Brent, A.; Goedkoop, M.; Heijungs, R.; Itsubo, N.; Pena, C.; Pennington, D.; Potting, J.; et al. The LCIA midpoint-damage framework of the UNEP/SETAC life cycle initiative. Int. J. Lca 2004, 9, 394-404. [CrossRef]

52. Steffen, W.; Richardson, K.; Rockström, J.; Cornell, S.E.; Fetzer, I.; Bennett, E.; Biggs, R.; Carpenter, S.R.; De Vries, W.; A De Wit, C.; et al. Sustainability. Planetary boundaries: Guiding human development on a changing planet. Science 2015, 347, 1259855. [CrossRef]

53. Ryberg, M.; Owsianiak, M.; Richardson, K.; Hauschild, M. Challenges in implementing a Planetary Boundaries based Life-Cycle Impact Assessment methodology. J. Clean. Prod. 2016, 139, 450-459. [CrossRef]

54. Sandin, G.; Peters, G.M.; Svanström, M. Using the planetary boundaries framework for setting impact-reduction targets in LCA contexts. Int. J. Life Cycle Assess. 2015, 20, 1684-1700. [CrossRef] 
55. Bjørn, A.; Hauschild, M.Z. Integrating planetary boundaries into the life cycle assessment framework for assessing absolute environmental sustainability of products and systems. In Proceedings of the Resilience 2014: Resilience and Development: Mobilizing for Transformation, Montpellier, France, 4-8 May 2014.

56. Sala, S. Global environmental impacts and planetary boundaries in LCA: Data sources and methodological choices for the calculation of global and consumption-based normalisation factors. JRC 2016. [CrossRef]

57. Hollberg, A.; Lützkendorf, T.; Habert, G. Top-down or bottom-up?-How environmental benchmarks can support the design process. Build. Environ. 2019, 153, 148-157. [CrossRef]

58. Eggleston, H.S. (Ed.) 2006 IPCC Guidelines for National Greenhouse Gas Inventories; Institute for Global Environmental Strategies: Hayama, Japan, 2006.

59. Bos, U.; Horn, R.; Beck, T.; Lindner, J.P.; Fischer, M. LANCA—Characterization Factors for Life Cycle Impact Assessment: Version 2.0; Fraunhofer Verlag: Stuttgart, Germany, 2016.

60. Fantke, P.; Bijster, M.; Hauschild, M.Z.; Huijbregts, M.; Jolliet, O.; Kounina, A.; Magaud, V.; Margni, M.; McKone, T.E.; Rosenbaum, R.K.; et al. USEtox ${ }^{\circledR} 2.0$ Documentation (Version 1.00); USEtox®Team: Lyngby, Denmark, 2017.

61. Persson, H.; Åhman, H.; Yngling, A.A.; Gulliksen, J. Universal design, inclusive design, accessible design, design for all: Different concepts-One goal? On the concept of accessibility-Historical, methodological and philosophical aspects. Univ. Access Inf. Soc. 2015, 14, 505-526. [CrossRef]

62. Alsayyar, B.; Jrade, A. Integrating Building Information Modeling (BIM) with Sustainable Universal Design Strategies to Evaluate the Costs and Benefits of Building Projects; The University of British Columbia: Vancouver, BC, Canada, 2015.

63. Griessler, E.; Littig, B. Social sustainability: A catchword between political pragmatism and social theory. Int. J. Sustain. Dev. 2005, 8, 65-79.

64. Grunwald, A.; Rösch, C. Sustainability assessment of energy technologies: Towards an integrative framework. Energy Sustain. Soc. 2011, 1. [CrossRef]

65. Leonardi, P.M. Materiality, Sociomateriality, and Socio-Technical Systems: What Do These Terms Mean? How are They Related? Do We Need Them? SSRN J. 2012. [CrossRef]

66. United Nations Sustainable Development Goals. Available online: https://www.undp.org/content/undp/en/ home/sustainable-development-goals.html (accessed on 21 September 2020).

67. Bundesregierung. German Sustainable Development Strategy: New Version 2016. Available online: https://www.bundesregierung.de/breg-en/issues/sustainability/germany-s-national-sustainabledevelopment-strategy-354566 (accessed on 21 September 2020).

68. Holler, M.; Krüger, T.; Mußmann, F. Die Weiterentwicklung des DGB-Index Gute Arbeit. Z. Arb. 2014, 68, 163-174. [CrossRef]

69. Federal Ministry for Economic Affairs and Energy. G20 Digital Economy: Ministerial Conference. 2017. Available online: https://g20.org/en/media/Documents/G20SS_Declaration_G20\%20Digital\%20Economy\% 20Ministers\%20Meeting_EN.pdf (accessed on 22 September 2020).

70. De Laat, P.B. Algorithmic Decision-Making Based on Machine Learning from Big Data: Can Transparency Restore Accountability? Philos. Technol. 2018, 31, 525-541. [CrossRef]

71. International Labour Organization. Good Practices and Challenges in Promoting Decent Work in Construction and Infrastructure Projects; International Labour Office: Geneva, Switzerland, 2015.

72. Bundesinstitut für Bau-, Stadt- und Raumforschung. Best Practice: Soziale Faktoren nachhaltiger Architektur. 17 Wohnungsbauprojekte im Betrieb; Bundesinstitut für Bau- Stadt- und Raumforschung (BBSR) im Bundesamt für Bauwesen und Raumordnung (BBR): Bonn, Germany, 2005.

73. United Nations Convention on the Rights of Persons with Disabilities (CRPD), Art.9. Available online: https://www.un.org/development/desa/disabilities/convention-on-the-rights-of-persons-withdisabilities/article-9-accessibility.html (accessed on 22 September 2020).

74. DGNB. DGNB System: Kriterienkatalog Gebäude Neubau, 3rd ed.; Deutsche Gesellschaft für Nachhaltiges Bauen: Stuttgart, Germany, 2018.

75. German Sustainable Building Council. Liveable \& Fit for the Future. People as the Center of Sustainable Construction. BUILD UP, 7 September 2019. Available online: https://www.buildup.eu/en/practices/ publications/liveable-fit-future-people-centre-sustainable-construction (accessed on 22 September 2020). 
76. Bundesministerium für Umwelt. Naturschutz, Bau und Reaktorsicherheit. Klimaschutzbericht 2016: Zum Aktionsprogramm Klimaschutz 2020 der Bundesregierung; Bundesministerium für Umwelt, Naturschutz, Bau und Reaktorsicherheit: Berlin, Germany, 2016.

77. Federal Ministry for the Environment. Nature Conservation, Building and Nuclear Safety. Guideline for Sustainable Building. Future-Proof Design, Construction and Operation of Buildings; Federal Ministry for the Environment, Nature Conservation, Building and Nuclear Safety: Berlin, Germany, 2019.

78. Hanc, M.; McAndrew, C.; Ucci, M. Conceptual approaches to wellbeing in buildings: A scoping review. Build. Res. Inf. 2019, 47, 767-783. [CrossRef]

79. Bundesministerium für Umwelt, Naturschutz, Bau und Reaktorsicherheit. Bewertungssystem Nachhaltiges Bauen (BNB). Büro- und Verwaltungsgebäude. BNB_BN3.1.7. 2015. Available online: https://www.bnb-nachhaltigesbauen.de/fileadmin/steckbriefe/verwaltungsgebaeude/neubau/v_2015/ BNB_BN2015_317.pdf (accessed on 22 September 2020).

80. Deutsches Institut für Normung, e.V. DIN EN 15978:2012-10, Nachhaltigkeit von Bauwerken_-Bewertung der umweltbezogenen Qualität von Gebäuden_-Berechnungsmethode; Deutsche Fassung EN_15978:2011. Available online: https://www.beuth.de/de/norm/din-en-15978/164252701 (accessed on 22 September 2020).

81. Brauner, P.; Ziefle, M. Why consider the human-in-the-loop in automated cyber-physical production systems? Two cases from cross-company cooperation. In Proceedings of the 2019 IEEE 17th International Conference on Industrial Informatics (INDIN), Helsinki, Finland, 22-25 June 2019; IEEE: Piscataway, NJ, USA, 2019; pp. 861-866.

82. Convention on the Rights of Persons with Disabilities and Optional Protocol: CRPD. Available online: https://www.un.org/disabilities/documents/convention/convoptprot-e.pdf (accessed on 22 September 2020).

(C) 2020 by the authors. Licensee MDPI, Basel, Switzerland. This article is an open access article distributed under the terms and conditions of the Creative Commons Attribution (CC BY) license (http://creativecommons.org/licenses/by/4.0/). 